\title{
Proteolysis and Microstructure of Piacentinu Ennese Cheese Made Using Different Farm Technologies ${ }^{1}$
}

\author{
V. Fallico, ${ }^{\star 2}$ L. Tuminello, ${ }^{\star}$ C. Pediliggieri, ${ }^{\star}$ J. Horne,† S. Carpino, ${ }^{\star}$ and G. Licitra ${ }^{\star} \ddagger$ \\ ${ }^{*}$ CoRFiLaC, Regione Siciliana, 97100 Ragusa, Italy \\ †InsightsNow, Inc., Corvallis, OR 97333 \\ ‡Department of Agronomic, Agrochemical Sciences and Animal Productions, \\ Catania University, 95100 Catania, Italy
}

\begin{abstract}
The aim of this study was to provide the biochemical and structural characterization of Piacentinu Ennese cheese and to evaluate the impact of different farm technologies on cheese proteolysis and microstructure. Fifteen cheeses were manufactured according to traditional technology, i.e., from raw milk and farmhouse rennet in the absence of starter culture. Pasteurized milk, commercial rennet, and starter were used for production of 20 nontraditional cheeses. Proteolysis in Piacentinu Ennese cheese was monitored during a 2- to 10 -mo ripening time. Low rates of overall proteolysis were observed in cheese, as percentages of total $\mathrm{N}$ soluble at $\mathrm{pH} 4.6$ and in $12 \%$ trichloroacetic acid were about 11.40 and $8.10 \%$, respectively, after $10 \mathrm{mo}$ of age. Patterns of primary proteolysis by urea-PAGE showed that $\alpha_{\mathrm{s}}$-caseins were degraded to a larger extent than were $\beta$ caseins, although a considerable amount of both caseins was still intact after 10 mo. Reversed phase-HPLC analysis of the cheese peptide fractions showed a slow decrease in the levels of hydrophobic peptides coupled to increasing levels of hydrophilic compounds as the cheese aged. The structural characteristics of Piacentinu Ennese cheese were evaluated by scanning electron microscopy after 2,4 , and 6 mo of age. The micrographs showed a sponge-like structural network with a well-distributed system of empty spaces, originally occupied by whey and fat. The microstructure changed during cheese ripening to become more compact with cavities of smaller size. Farm technology significantly affected cheese proteolysis and microstructure. Nontraditional cheeses had higher levels of $\mathrm{pH} 4.6$-soluble $\mathrm{N}$ and showed a larger hydrolysis of $\alpha_{\mathrm{s}}$-casein fractions by urea-PAGE analysis than did traditional cheeses.
\end{abstract}

\footnotetext{
Received July 15, 2005.

Accepted September 28, 2005.

${ }^{1}$ Use of names, names of ingredients, and identification of specific models of equipment is for scientific clarity and does not constitute any endorsement of the product by the authors, CoRFiLaC, InsightsNow, or Catania University.

${ }^{2}$ Corresponding author: enzofallico@corfilac.it
}

Large differences between cheese-types also concerned the patterns of secondary proteolysis. Nontraditional cheeses had higher levels of $12 \%$ trichloroacetic acidsoluble $\mathrm{N}$ and showed larger proportions of free amino acids and hydrophilic peptides in the HPLC profiles of the corresponding $70 \%$ ethanol-soluble $\mathrm{N}$ fraction than traditional cheeses. Nontraditional cheeses also had a more open structure with a coarser and less continuous appearance than did traditional cheeses. A large amount of variability in cheese proteolysis and structure within nontraditional treatment reflected farmdependent changes in manufacturing conditions related to the use of various types of rennet and starter. Key words: Piacentinu Ennese cheese, proteolysis, microstructure, farm technology

\section{INTRODUCTION}

Piacentinu Ennese is a hard-pressed ewes' milk cheese of Sicily, exclusively produced in the homonymous province of Enna (Italy) in the amount of 35 tonne/yr. The traditional technology and tools used for cheese manufacture are almost equivalent to those for the Protected Denomination of Origin Pecorino Siciliano cheese (Gazzetta Ufficiale della Comunità Europea, 1996); the only distinctive difference is related to the addition of saffron to the milk before coagulation. This spice confers the cheese with a bright yellow color and potentially different sensory and health properties from other types of Pecorino cheeses (D'Auria et al., 2004). Piacentinu Ennese is traditionally made using raw milk, farmhouse rennet, and no starter culture; some producers use pasteurized milk, commercial rennet, and starter in the cheese production. The main purpose of this nontraditional methodology is to provide acceptable safety and standard levels of quality in cheese according to the increasing attention by the European Community policies toward food hygiene and safety aspects. Pasteurization of milk before cheese manufacture is intended to reduce microbial loads and eliminate pathogens and most of the spoilage microorganisms that may be present in milk (Grappin and Beuvier, 
1997). However, milk pasteurization is also known to adversely affect the development of many sensory properties of cheese. Generally, pasteurized milk cheeses ripen slower and develop a less intense and diversified flavor than raw milk cheeses in part because of the lower contents of free AA (FAA), fatty acids, and volatile compounds (McSweeney et al., 1993; Beuvier et al., 1997; Grappin and Beuvier, 1997). Milk pasteurization also affects cheese texture, giving rise to an open structure with numerous and irregular cavities that is less firm and more fracturable compared with that of raw milk cheeses (Creamer and Olson, 1982; Lau et al., 1991; Buffa et al., 2001). These differences in cheese quality have been ascribed to the deactivation of the indigenous microflora in pasteurized milk cheeses. McSweeney et al. (1993) observed that the less intense flavor in pasteurized milk compared with raw milk Cheddar cheese was due to the lower number and less diversified community of nonstarter lactic acid bacteria (NSLAB), such as mesophilic lactobacilli, in the former. The biodiversity of the native milk microflora is indeed accepted to give raw milk cheeses specific sensory properties and is considered to be a distinctive aspect of traditional cheeses. Replacing the native milk microflora by the standard culture starters may result in standardization of these attributes and loss of individual cheese personality.

The influence of pasteurization on proteolysis of cheese from cow milk (Lau et al., 1991; McSweeney et al., 1993; Beuvier et al., 1997; Skeie and Ardö, 2000), ewe milk (Ordónez et al., 1999; Albenzio et al., 2001), and goat milk (Trujillo et al., 2002) has been largely described. These studies have shown that little consistency exists, among different cheese varieties, in relation to the influence of milk pasteurization on profiles of cheese proteolysis. Grappin and Beuvier (1997) reviewed the literature, concluding that pasteurization had a negligible and variable effect on primary proteolysis, dependent on the type of cheese. Its specific impact on casein hydrolysis is often partially or totally concealed by the influence that different manufacturing parameters and physiochemical characteristics, related to different cheese varieties, may exert on the activity of proteases. Otherwise, the negative impact of milk pasteurization on the levels of FAA and small peptides, obtained by affecting the populations and the activity of peptidases from raw milk flora, has been clearly demonstrated. In Cheddar cheese, the contribution of NSLAB to cheese ripening has been shown to be mainly at the level of FAA formation and cheese flavor intensification, whereas starter bacteria make a greater contribution to secondary proteolysis (Lane and Fox, 1996; Lynch et al., 1996, 1997). Changes in the type of rennet used for milk coagulation may potentially introduce further variability in proteolysis profiles of cheeses. Traditional manufacturing of Piacentinu Ennese makes use of farmhouse rennet as a coagulant, which is obtained by macerating abomasa from young lambs in salted brine. Commercial rennet paste is instead used in nontraditional cheese production. Commercial coagulants are generally characterized with various enzymatic composition and clotting activities; therefore, they may produce different extents of cheese proteolysis. Prieto et al. (2004) reported significantly higher contents of both $\mathrm{pH} 4.6$-soluble $\mathrm{N}$ and $12 \%$ TCA-soluble $\mathrm{N}$ in Leòn raw milk cheese made using commercial rennet compared with the cheeses made using farmhouse rennet.

Horne et al. (2005) recently showed that Piacentinu Ennese cheeses made using nontraditional technology clearly had different volatile fingerprints, both in numbers and types of volatile organic compounds present, from those made using traditional means. However, to date, little attention has been paid to proteolysis and microstructure of these cheeses. The objective of this study was to provide the biochemical and structural characterization of Piacentinu Ennese cheese and to evaluate the impact of different farm technologies on cheese proteolysis and microstructure during a 2- to 10 -mo ripening time.

\section{MATERIALS AND METHODS}

\section{Cheese Sampling}

Piacentinu Ennese cheeses $(n=35)$ were collected from 7 farms in the province of Enna (Italy). Fifteen cheeses were produced according to traditional technology by coagulating raw milk via farmhouse lamb or kids' rennet in absence of starter cultures. Twenty cheeses were produced according to nontraditional technology, i.e., from pasteurized milk using various types of thermophilic or mesophilic starter cultures and commercial lamb or kids' rennet paste, depending upon farm. Details of cheese manufacture according to traditional and nontraditional technologies are reported and compared in Figure 1. After production, all cheeses were transported to the Experimental Dairy Plant of CoRFi$L a C$ to be aged 2 to 10 mo under the same conditions.

\section{Compositional Analysis}

Grated cheese samples were analyzed as follows: total $\mathrm{N}$ by the Kjeldahl method (IDF, 1993), fat by the Gerber method (IDF, 1997), and NaCl by the Volhard method (AOAC, 2000). Nitrogen soluble in an acetate buffer at $\mathrm{pH} 4.6$ (pH4.6SN) and in $12 \%$ TCA (TCASN) were determined (Bynum and Barbano, 1985) and expressed as a percentage of the total $\mathrm{N}$ content. All of 
Raw whole ewes' milk

Milk is filtered into a tin copper vat and warmed by direct wooden flame (milk temperature: $26.9^{\circ} \mathrm{C}$; milk $\mathrm{pH}: 6.57$ )

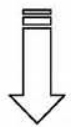

\begin{tabular}{|c|}
\hline $\begin{array}{c}\text { Saffron addition } \\
\text { Addition of ground (or toasted, ground, and filtered) } \\
\text { saffron to milk }(7 \mathrm{~g} / 100 \mathrm{~L})\end{array}$ \\
\hline $\begin{array}{c}\text { Coagulation } \\
\text { Addition of farmhouse lamb and/or kid rennet paste to milk }(42 \mathrm{~g} / 100 \mathrm{~L}) \\
\left.\text { (milk temperature: } 35^{\circ} \mathrm{C} \text {; coagulation time: } 50 \mathrm{~min}\right)\end{array}$ \\
\hline
\end{tabular}

\section{Cutting of the curd}

The curd is broken by hand with a wooden staff with a wooden ball at one end (the "rotula") using a circular stirring motion(cutting time: 5 min;

curd temperature: $34.2^{\circ} \mathrm{C}$ )

\section{First cooking}

Addition of hot water $\left(\mathrm{ca} .83^{\circ} \mathrm{C}\right)$ producing an increase of curd temperature of about $8^{\circ} \mathrm{C}$ (curd temperature: $42.7^{\circ} \mathrm{C}$; curd size: maize grains; cooking time: $25 \mathrm{~min}$ )

\section{Drawing of the whey}

After curd settling, whey is removed and placed in an another vat for the manufacture of ricotta

\section{Curd forming and pressing}

Curd is manually placed and pressed into a reed basket, sometimes with grains of black pepper (curd temperature: $40.1^{\circ} \mathrm{C}$; curd $\mathrm{pH}$ : 6.42)

\section{Curd turning and draining}

Curd is turned upside down within the reed basket and left to drain on a wooden table (the "tavulieri") while ricotta is made (draining time: 80 min; curd temperature: $38^{\circ} \mathrm{C}$; curd $\mathrm{pH}: 6.36$

\section{Second cooking}

Curd, within the reed basket, is placed and left immersed in hot ricotta whey [the "scotta" (ca. $\left.78^{\circ} \mathrm{C}\right)$ ] left over from the manufacture of ricotta (cooking time: $180 \mathrm{~min}$; curd temperature: $50^{\circ} \mathrm{C}$; curd pH: 5.55)

\section{Curd turning and ripening}

Curd is separated from scotta, turned upside down within the reed basket, and left to ripen (i.e., develop acid) on a wooden table (the "tavulieri") for about $15 \mathrm{~h}$ at ambient temperature

\section{Dry salting}

Curd is removed from the reed basket, transferred to the aging center, and dry-salted by hand on the entire surface. During a 20 - to 30 -d period, the cheese is continously turned, spreading the surface with the same salt discharged from the cheese or with brine

\begin{tabular}{|c|}
\hline Aging \\
Traditional aging center are natural caves or cellar (temperature: 8 to \\
$16^{\circ} \mathrm{C}$; relative humidity: 80 to $99 \%$ ). Aging time varies depending upon \\
cheese tipology (primosale: 15 to $30 \mathrm{~d}$; semi-aged: 2 to 4 mo; aged: \\
4 to $12 \mathrm{mo}$ )
\end{tabular}

Pasteurization of whole ewes' milk

Milk is heated at $70^{\circ} \mathrm{C}$ for $30 \mathrm{~s}$, cooled at ca. $39^{\circ} \mathrm{C}$, and then transferred to a stainless steel vat

\section{Starter culture addition}

Addition of starter (Streptococcus thermophilus and Lactococcus lactis or Lactobacillus bulgaricus) to milk ( $2.2 \mathrm{~g} / 100 \mathrm{~L})$ (milk temperature: $32.3^{\circ} \mathrm{C}$; milk $\mathrm{pH}: 6.49$ )

Saffron addition
Addition of ground (or toasted, ground, and filtered) saffron to pasteurized
milk $(6 \mathrm{~g} / 100 \mathrm{~L})$

\section{Coagulation}

Addition of commercial lamb and/or kid rennet paste to milk (37 g/100 L) (milk temperature: $37^{\circ} \mathrm{C}$; coagulation time: $42 \mathrm{~min}$ )

Cutting of the curd

The curd is broken by vertical wiring blades using a circular stirring motion (cutting time: $11 \mathrm{~min}$; curd temperature: $37^{\circ} \mathrm{C}$ )

\section{First cooking}

During the cutting, curd is indirectly warmed by steam, producing an increase of curd temperature about $2^{\circ} \mathrm{C}$ (curd temperature: $39^{\circ} \mathrm{C}$; curd size: hazelnut grains; cooking time: $11 \mathrm{~min}$ )

\section{Drawing of the whey}

Curd-whey mixture is decanted into a stainless steel table from which whey flows into another vat for the manufacture of ricotta

\section{Curd forming and pressing}

Curd is manually placed and pressed into a reed basket, sometimes with grains of black pepper (curd temperature: $38^{\circ} \mathrm{C}$; curd pH: 6.42)

\section{Curd turning and draining}

Curd is turned upside down within the reed basket and left to drain on a stainless steel table while ricotta is made (draining time: 45 min; curd temperature: $38^{\circ} \mathrm{C}$; curd $\mathrm{pH}: 6.35$ )

\section{Second cooking}

Curd, within the reed basket, is placed and left immersed in hot ricotta whey [the "scotta" (ca. $\left.74^{\circ} \mathrm{C}\right)$ ] left over from the manufacture of ricotta (cooking time: 100 min; curd temperature: $45^{\circ} \mathrm{C}$; curd pH: 5.47)

\section{Curd turning and ripening \\ Curd is separated from scotta, turned upside down within the reed basket, and left to ripen (i.e., develop acid) on a stainless steel table for about $20 \mathrm{~h}$} at ambient temperature

Dry salting
$\begin{gathered}\text { Curd is removed from the reed basket, transferred to the aging center, and } \\ \text { dry-salted by hand on the entire surface. During a } 20 \text { - to } 30-\mathrm{d} \text { period, the } \\ \text { cheese is continously turned, spreading the surface with the same salt } \\ \text { discharged from the cheese or with brine }\end{gathered}$

Aging
Cheese aging takes place within rooms at controlled temperature and
humidity (temperature: 9 to $14^{\circ} \mathrm{C}$; relative humidity: 90 to $99 \%$ ). Aging
time varies depending on cheese tipology (primosale: 15 to $30 \mathrm{~d}$;
semi-aged: 2 to 4 mo; aged: 4 to $12 \mathrm{mo}$ )

Figure 1. Protocol of Piacentinu Ennese cheese manufacture according to the traditional (left) and nontraditional (right) technology. 
these analyses were made in duplicate. Total solids were determined in 4 replicates using a forced-air, ovendrying method at $100^{\circ} \mathrm{C}$ for $24 \mathrm{~h}$ (AOAC, 2000).

\section{Assessment of Proteolysis}

The $\mathrm{pH} 4.6$-insoluble $\mathrm{N}$ of the cheeses was prepared as described by Fallico et al. (2004). These fractions were analyzed by urea-PAGE using a Protean IIxi vertical slab gel unit (BioRad Laboratories Ltd., Watford, Herts, United Kingdom) according to the method of Andrews (1983). The gels were stained using a modification of the method of Blakesley and Boezi (1977) with Coomassie Brilliant Blue G250. Cheese N fractions soluble (ESN) and insoluble (EIN) in $70 \%$ ethanol were prepared from $\mathrm{pH} 4.6 \mathrm{SN}$ according to Kuchroo and Fox (1982). Freeze-dried aliquots of the ESN and EIN cheese extracts were analyzed by reverse phase-HPLC (RP-HPLC) as described by Lynch et al. (1996).

\section{Statistical Analysis}

A 2-way nested ANOVA model was used to assess the effects of farm technology (traditional or nontraditional) and aging time $(2,4,6,8$, and $10 \mathrm{mo})$ on 8 chemical variables that were treated as dependent variables. Farm technology and cheese age were treated as fixed main effects; farm was treated as a random effect and was nested within farm technology. When significant main effects were found $(P \leq 0.05)$, specific mean differences were determined using Tukey's Honestly Significant Difference test. Univariate analyses were performed using procedures GLM in SAS v.8.2 (SAS Inst., Inc., Cary, NC).

\section{Scanning Electron Microscopy}

A cylinder, $6 \mathrm{~cm}$ in length $\times 1 \mathrm{~cm}$ in diameter, was extracted from each cheese using a cork borer; three 1$\mathrm{mm}$ thick slices were removed from approximately the center of each cylinder to give samples deriving from the medium zone of the cheese. A square portion ( $4 \mathrm{~mm}$ $\times 4 \mathrm{~mm}$ ) was then removed from the center of each round slice by a blade. Cheese samples were prepared for scanning electron microscopy (SEM) analysis according to the procedure of Rousseau (1988) with some modifications. Samples were fixed in $2.5 \%$ (wt/vol) glutaraldehyde in a $0.1 M$ sodium cacodylate buffer (Sigma-Aldrich, Steinheim, Germany) ( $\mathrm{pH}$ 7.2) for $3 \mathrm{~d}$ at $4^{\circ} \mathrm{C}$. Fixed samples were rinsed with the cacodylate buffer for $10 \mathrm{~min}$ at room temperature. This step was repeated 3 times. Dehydration was carried out using a graded ethanol (Fluka, Sigma-Aldrich) series (10, 25, $50,75,85$, and $95 \%$, vol/vol) for $10 \mathrm{~min}$ in each bath at room temperature and then absolute ethanol for $1 \mathrm{~h}$ at $4^{\circ} \mathrm{C}$. After these steps, absolute ethanol was removed, and new absolute ethanol was added for maintenance at room temperature. Samples were dried by the critical point method in $\mathrm{CO}_{2}$ using a Polaron CPD 7501 (Polaron, Watford, UK) and then fractured into small pieces by a blade. Fractured dried samples were mounted on SEM aluminum stubs using a carbon adhesive (SPI Supplies, West Chester, PA) and then coated (ca. $18 \mathrm{~nm}$ thick) with gold-palladium in a Polaron SC7620 mini-sputter coater in argon medium. Cheese samples were examined in an JEOL JSM-5900-LV scanning electron microscope (JEOL, Tokyo, Japan) with a voltage of $15 \mathrm{kV}$ and a working distance of 15 to $22 \mathrm{~mm}$. Images were recorded at 1,600 and $3,300 \times$ magnification.

\section{RESULTS AND DISCUSSION}

\section{Chemical Composition}

Overall means for the gross composition of Piacentinu Ennese as functions of cheese age and farm technology, respectively, are shown in Table 1. Aging time had the largest impact on cheese composition, significantly ( $P$ $<0.05$ ) affecting the changes in all chemical parameters except for the content of fat in DM. Mean values for this parameter ranged from 50.7 to $52.8 \%$, approaching those reported for Idiazábal and Manchego cheeses and exceeding those for Roncal (Freitas and Malcata, 2000) and Canestrato Pugliese (Albenzio et al., 2001). Levels of protein and salt-in-moisture $(\mathbf{S} / \mathbf{M})$ significantly $(P<$ 0.05) increased during cheese ripening as a result of the significant decrease in moisture content. The S/M levels of Piacentinu Ennese cheese at the end of the ripening (12.80\%) were higher than those of Canestrato Pugliese (8.9\%) and Fiore Sardo (5.6\%) but were much lower than those of Pecorino Romano (24.5\%); all cheeses ripened 12 mo (Di Cagno et al., 2003). Differences in S/M levels among these cheeses were mainly related to different dry salting times. The manufacture of Piacentinu Ennese cheese includes a dry salting for 20 to $30 \mathrm{~d}$. The same process lasts only 4 to $6 \mathrm{~d}$ in Canestrato Pugliese and Fiore Sardo, but is more prolonged ( 30 to $60 \mathrm{~d}$ ) in Pecorino Romano cheese (Medina and Nunez, 2004). Proteolysis in cheese is often measured by means of quantification of cheese $\mathrm{pH} 4.6 \mathrm{SN}$ and TCASN buffers. The majority of $\mathrm{pH} 4.6 \mathrm{SN}$ is made up of large- and medium-sized peptides, produced by the action of residual rennet and plasmin, but it also contains small-sized peptides, FAA, and their catabolites produced by microflora. Conversely, TCASN consists primarily of small peptides, FAA, and other minor nitrogenous compounds produced by both starter and nonstarter bacteria (Sousa et al., 2001). Both pH4.6SN 
Table 1. Overall means $( \pm \mathrm{SD})$ for the effects of aging time and farm technology on the gross composition of Piacentinu Ennese cheese ${ }^{1}$

\begin{tabular}{|c|c|c|c|c|c|c|c|}
\hline & \multirow{2}{*}{\multicolumn{5}{|c|}{ Aging time (mo) }} & \multicolumn{2}{|c|}{ Farm technology } \\
\hline & & & & & & \multirow{2}{*}{$\begin{array}{l}\text { Traditional } \\
(\mathrm{n}=15)\end{array}$} & \multirow{2}{*}{$\begin{array}{l}\text { Nontraditional } \\
(\mathrm{n}=20)\end{array}$} \\
\hline & $2(\mathrm{n}=7)$ & $4(\mathrm{n}=7)$ & $6(\mathrm{n}=7)$ & $8(n=7)$ & $10(\mathrm{n}=7)$ & & \\
\hline Moisture, \% & $32.49^{\mathrm{a}}$ & $30.23^{\mathrm{b}}$ & $28.02^{\mathrm{c}}$ & $27.19^{\mathrm{c}}$ & $26.69^{\mathrm{c}}$ & $28.75 \pm 2.75$ & $29.05 \pm 2.70$ \\
\hline Protein, \% & $26.83^{\mathrm{c}}$ & $27.65^{\text {bc }}$ & $28.80^{\mathrm{ab}}$ & $29.15^{\mathrm{ab}}$ & $29.67^{\mathrm{a}}$ & $29.11 \pm 1.85$ & $27.90 \pm 1.92$ \\
\hline Fat in DM, \% & 52.77 & 50.96 & 51.71 & 52.26 & 50.70 & $51.35 \pm 3.11$ & $51.93 \pm 2.64$ \\
\hline $\mathrm{S} / \mathrm{M}, \%$ & $8.86^{\mathrm{b}}$ & $11.23^{\mathrm{a}}$ & $11.33^{\mathrm{a}}$ & $12.27^{\mathrm{a}}$ & $12.80^{\mathrm{a}}$ & $10.45 \pm 2.81$ & $11.94 \pm 4.08$ \\
\hline TCASN/pH4.6SN, \% & $49.84^{\mathrm{bc}}$ & $46.60^{\mathrm{c}}$ & $57.14^{\mathrm{bc}}$ & $58.54^{\mathrm{b}}$ & $71.39^{\mathrm{a}}$ & $51.26 \pm 12.35$ & $60.78 \pm 12.12$ \\
\hline
\end{tabular}

a,b,c Means sharing common subscripts were not significantly different $(P<0.05)$.

${ }^{1}$ Protein $=$ total $\mathrm{N} \times 6.38, \mathrm{~S} / \mathrm{M}($ salt-in-moisture $)=[(\mathrm{NaCl}) /($ moisture content $)] \times 100 ; \mathrm{pH} 4.6 \mathrm{SN} /$ total $\mathrm{N}=\mathrm{pH} 4.6$ acetate buffer-soluble $\mathrm{N}$ as a percentage of total $\mathrm{N}$; TCASN/total $\mathrm{N}=12 \%$ TCA-soluble $\mathrm{N}$ as a percentage of total $\mathrm{N}$; and TCASN/pH4.6SN $=12 \%$ TCA-soluble $\mathrm{N}$ as a percentage of $\mathrm{pH} 4.6$ acetate buffer-soluble $\mathrm{N}$.

and TCASN, expressed as a percentage of total N, significantly $(P<0.05)$ increased in Piacentinu Ennese as the cheese aged. However, both proteolysis indices were much lower compared with other ewes' milk cheese varieties, such as Canestrato Pugliese, Fiore Sardo, Pecorino Romano (Guinee and Fox, 1984; Di Cagno et al., 2003), Fossa (Gobbetti et al., 1999), and Idiazábal (Mendia et al., 2000), indicating low rates of overall proteolysis. The high levels of S/M characterizing Piacentinu Ennese cheese throughout aging $(8.86 \%$ at 2 mo up to $12.80 \%$ after 10 mo) might have exerted a negative influence on the rate and extent of casein hydrolysis. Increasing $\mathrm{S} / \mathrm{M}$ is known indeed to inhibit rennet and microbial activities in cheese for different reasons. Proteolysis of caseins, mainly of $\beta$-CN, by coagulant has been found to be significantly reduced by $5 \% \mathrm{~S} / \mathrm{M}$ and completely inhibited in the presence of $10 \% \mathrm{~S} / \mathrm{M}$ (Fox and Walley, 1971). Otherwise, the enzymatic activities of microflora are limited by a lowering of water activity resulting from the decrease in moisture associated to increasing salt (Beresford and Williams, 2004). Among the cheese varieties compared, only Pecorino Romano had higher levels of S/M than Piacentinu Ennese cheese at similar stages of ripening (Guinee and Fox, 1984; Di Cagno et al., 2003). Finally, the ratio of TCASN to pH4.6SN, measuring the "depth" of cheese proteolysis, significantly $(P<0.05)$ increased with the age of Piacentinu Ennese as well. This finding suggested that largeand medium-sized peptides, produced by primary action of chymosin and plasmin on caseins, were progressively converted into small peptides and FAA by the microflora peptidases acting during cheese ripening (Beresford and Williams, 2004).

Rates of proteolysis in Piacentinu Ennese cheese were found to be significantly $(P<0.05)$ affected by farm technology. Levels of pH4.6SN and TCASN, expressed as percentages of total $\mathrm{N}$, were significantly $(P$
$<0.05)$ higher in nontraditional cheeses than in traditional counterparts. These findings were in disagreement with most of the results from similar studies, where cheeses made from pasteurized milk are generally reported to have similar or lower levels of $\mathrm{pH} 4.6 \mathrm{SN}$ and TCASN than raw milk cheeses (Gaya et al., 1990; Lau et al., 1991; Beuvier et al., 1997; Albenzio et al., 2001). However, it is known that contradictory results have been described for the effects of milk pasteurization on primary and secondary proteolysis, depending on the cheese variety (Grappin and Beuvier, 1997). Researchers working on Cheddar (Rosenberg et al., 1995), Idiazábal (Mendia et al., 2000), Serra da Estrela (Sousa and Malcata, 1996), and semi-hard goats' milk cheeses (Trujillo et al., 2002) obtained results consistent with our findings; i.e., cheeses made from pasteurized ewes' milk with native added starter had the highest levels of soluble nitrogenous fractions. Prieto et al. (2004) studied the effects of the type of coagulant on proteolysis of León cows' milk cheese and reported significantly higher contents of $\mathrm{pH} 4.6 \mathrm{SN}$ and TCASN in cheeses made using commercial rennet than in those made using farmhouse rennet. Differences in the levels of proteolysis between nontraditional and traditional cheeses might have been caused also by changes in the levels of residual coagulant, as a greater retention of rennet was reported in cheeses made from pasteurized milk compared with those made from raw milk (Gaya et al., 1990). A large contribution of plasmin to primary proteolysis of nontraditional cheeses may also be suggested, as its activity is known to be increased by the heat processing of milk (Grappin and Beuvier, 1997). The higher levels of TCASN in nontraditional compared with traditional cheeses were probably due to the larger impact that starter bacteria exert on secondary proteolysis compared with NSLAB (Lane and Fox, 1996; Lynch et al., 1996, 1997). The highest levels of thermophilic 

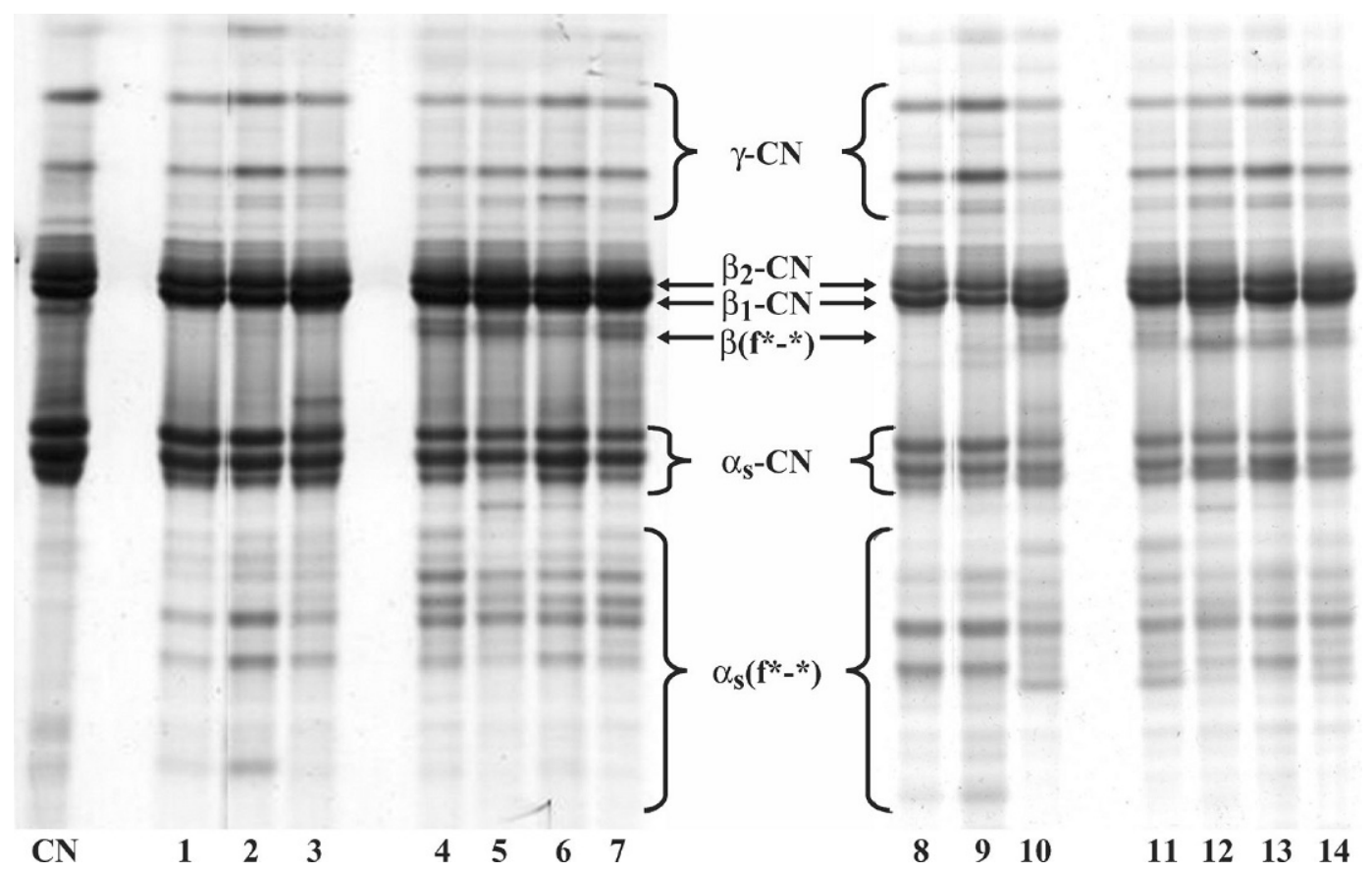

Figure 2. Urea-PAGE ( $\mathrm{pH}$ 8.6) of $\mathrm{pH}$ 4.6-insoluble $\mathrm{N}$ fraction of Piacentinu Ennese cheese made using the traditional technology after 2 (Lanes 1 to 3) and 10 mo (Lanes 8 to 10) of age, in comparison with cheeses made using the nontraditional technology after 2 (Lanes 4 to 7) and 10 mo (Lanes 11 to 14 ) of age. Whole ovine casein was used as a reference standard.

lactic acid bacteria found in nontraditional cheeses by Horne et al. (2005) support this hypothesis. Finally, despite the generally higher mean values for nontraditional cheeses compared with traditional cheeses, farm technology had no significant $(P>0.05)$ influence on the remaining chemical parameters.

\section{Electrophoretic Analysis}

Primary proteolysis in Piacentinu Ennese cheese produced according to different farm technologies was compared by urea-PAGE analysis of the $\mathrm{pH} 4.6$-insoluble $\mathrm{N}$ fraction (Figure 2). Native caseins in ewes' milk cheeses are distributed within 2 groups of bands showing different electrophoretic mobility. The group with lower mobility consists of 2 genetic variants $\left(\beta_{1}\right.$ and $\left.\beta_{2}\right)$ of $\beta$-CN, which differ in the level of phosphorylation (6 and 5 phosphate groups, respectively). The group with higher mobility is formed instead with 3 fractions of $\alpha_{\mathrm{s}}-\mathrm{CN}$, whose microheterogeneity is due to different degrees of glycosylation or phosphorylation coupled with genetic polymorphism (Sousa and Malcata, 1998). Moderate hydrolysis of $\alpha_{\mathrm{s}}-\mathrm{CN}$ and $\beta$-CN fractions were common features of both traditional and nontraditional cheese profiles after 2 mo of age. A slight increase in proteolysis occurred in both cheese-types during aging, although a considerable amount of native caseins remained intact after 10 mo of age. This finding was in agreement with the very low level of primary proteolysis, measured as pH4.6SN, that was found in Piacentinu Ennese (Table 1). Regardless of cheese-type and age, the $\alpha_{\mathrm{s}}-\mathrm{CN}$ fractions were degraded to a larger extent than $\beta$-CN, which was similar to the trends reported for Canestrato Pugliese (Albenzio et al., 2001), Fiore Sardo, Pecorino Romano (Di Cagno et al., 2003), and Roncal (Irigoyen et al., 2000). Chymosin is thought to be largely inactivated by the high cooking temperatures $\left(50\right.$ to $\left.55^{\circ} \mathrm{C}\right)$ used during the manufacture of most hard cheese varieties (e.g., Parmigiano Reggiano, Swiss-type cheeses; Sousa et al., 2001). However, the lower temperatures $\left(45^{\circ} \mathrm{C}\right)$ used for cooking of curd in Pecorino cheeses, compared with the hard varieties, probably result in larger residual rennet activity producing extensive hydrolysis of $\alpha_{\mathrm{s}}$-CN. Minor degradation of $\beta$-CN at the beginning of cheese ripening was associated with a small production of $\gamma-\mathrm{CN}$, indicating limited activity of plasmin. Although increasing levels of $\gamma$-CN were found as the cheese aged, plasmin seemed to play a minor role in the proteolytic maturation of Piacentinu Ennese.

Farm technology affected the electrophoretic profiles of primary proteolysis in cheese, varying the patterns of peptides produced. A larger hydrolysis of $\alpha_{\mathrm{s}}-\mathrm{CN}$ fractions occurred in nontraditional cheeses compared with traditional cheeses, leading to the production of a greater number of peptides moving in the high mobility 
side of the gel. Similar electrophoretic profiles were reported for Canestrato Pugliese (Albenzio et al., 2001) and Idiazábal (Mendia et al., 2000) ewes' milk cheeses. Nontraditional cheese also had a higher level of pH4.6SN (Table 1), made up of nitrogenous compounds that are principally due to the action of residual coagulant. Both findings suggested an increased activity of coagulant in nontraditional cheeses, which was probably related to the use of commercial rennet that was reported to have higher enzymatic activity than farmhouse rennet (Prieto et al., 2004) and was also related to the greater retention of coagulant caused by milk pasteurization (Gaya et al., 1990). Plasmin is known to contribute to $\mathrm{pH} 4.6 \mathrm{SN}$ and to determine the highest levels of proteolysis in cheeses from pasteurized milk also (Grappin et al., 1985). Unexpectedly, plasmin activity seemed to be unaffected by thermal treatment of milk, as similar levels of $\gamma$-CN were measured between traditional and nontraditional cheeses (results not shown). This finding was consistent with the general trend that showed great resistance of $\beta$-CN fractions to hydrolysis during aging of Piacentinu Ennese. McSweeney et al. (1993) found no difference in the level of $\beta$-CN hydrolysis between pasteurized and raw milk Cheddar cheese, and similar results were obtained by others working on different cheese varieties, such as Arzua (Centeno et al., 1994) and Canestrato Pugliese (Albenzio et al., 2001). These results have been attributed to a lower level of plasmin activity compared with other hard cheese varieties (e.g., Swiss-type and Manchego) or, more likely, to the elimination of raw milk microflora caused by the pasteurization process (Grappin and Beuvier, 1997). Finally, the largest extent of primary proteolysis in nontraditional cheeses distinctively produced 2 peptides migrating faster than $\beta-\mathrm{CN}$ in the correspondent electrophoretic profiles.

\section{RP-HPLC Analysis of EIN and ESN}

Chromatograms of the EIN and ESN fractions of traditional and nontraditional cheeses at different ages $(2,4,6,8$, and $10 \mathrm{mo})$ are shown in Figures 3 and 4, respectively. Farm technology was found to affect the qualitative HPLC profiles of Piacentinu Ennese cheese. A larger proportion of peptides eluted at high acetonitrile concentrations in the chromatograms of the EIN fraction of traditional cheeses compared with NT counterparts, mainly at the beginning of cheese ripening (Figure 3). Differences in peptide profiles between cheese-types became less evident as the cheeses aged; hydrophobic peak heights progressively decreased, and eluting peaks appeared early. Qualitative differences were also found between the ESN fractions of traditional and nontraditional cheeses by RP-HPLC analysis
(Figure 4). Larger amounts of FAA and hydrophilic peptides eluted in the first 35 min of chromatograms of nontraditional cheeses compared with those of traditional cheeses; these latter cheeses showed a higher proportion of hydrophobic peptides. Larger amounts of soluble compounds in the ESN cheese fraction were in agreement with the higher levels of TCASN (Table 1) that were found in nontraditional compared with traditional cheeses. These findings suggested that peptidase activities from commercial starters made a greater contribution to secondary proteolysis in Piacentinu Ennese cheese than raw milk microbiota. The highest levels of thermophilic lactic acid bacteria found in nontraditional cheeses by Horne et al. (2005) supported this hypothesis. However, it was likely that the enzymatic activities of adventitious microflora surviving the pasteurization process or deriving from the manufacturing environment (Beresford and Williams, 2004) also provided a contribution to the larger production of soluble peptides and FAA in nontraditional cheeses. Farm-dependent differences were found among the HPLC profiles of traditional and nontraditional cheeses, showing that there was also a large amount of variability within farm technology.

Literature data concerning the influence of milk pasteurization on cheese peptide profiles were again almost contradictory. In agreement with our findings, Albenzio et al. (2001) observed large differences between the HPLC profiles of raw and pasteurized milk Canestrato Pugliese cheese; the latter lacked some of the peptides in the hydrophobic zone. Gomez et al. (1997) and Trujillo et al. (2002), instead, found similar levels of hydrophobic and hydrophilic peptides in the water-soluble fraction of Hispanico and of a semi-hard goats' milk cheese, respectively, made from pasteurized and raw milk. The reports of Lau et al. (1991) and McSweeney et al. (1993) for Cheddar cheese were in opposition to our findings. Cheddar made from pasteurized milk had a generally higher concentration of hydrophobic peptides, resulting in a higher hydrophobic to hydrophilic peptide ratio than raw milk cheese. Both groups of researchers attributed these differences to the aminopeptidase activities of NSLAB.

\section{Cheese Microstructure}

The structural characteristics of traditional and nontraditional Piacentinu Ennese cheese after 2, 4, and 6 mo of age are shown in Figure 5. The protein matrix of traditional cheese (Figure 5a, b, c) has a sponge-like structure permeated by a well-distributed system of empty spaces that were originally occupied by fat globules and whey. Casein micelles join each other to form clusters and strands with no defined orientation; this 

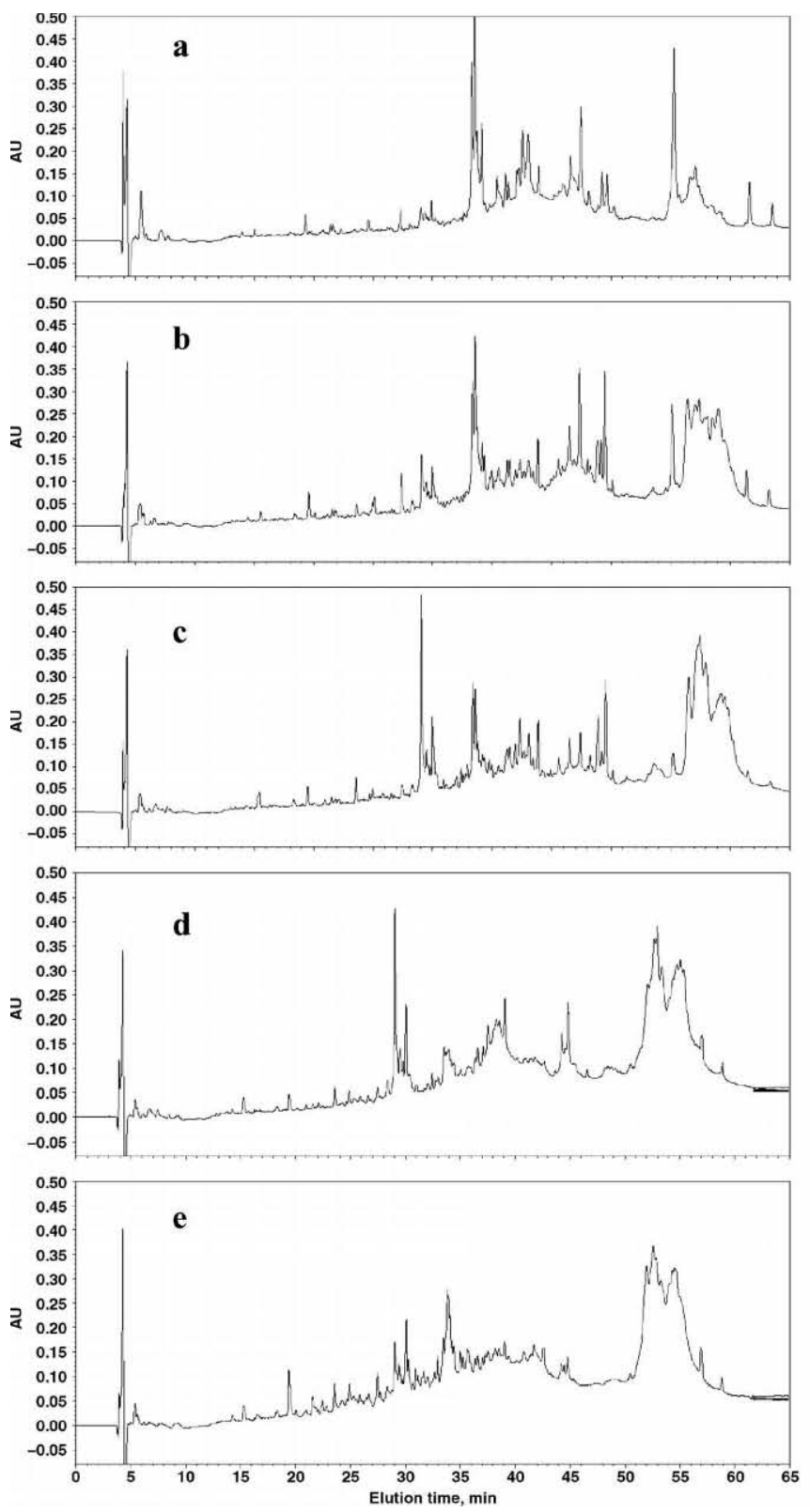
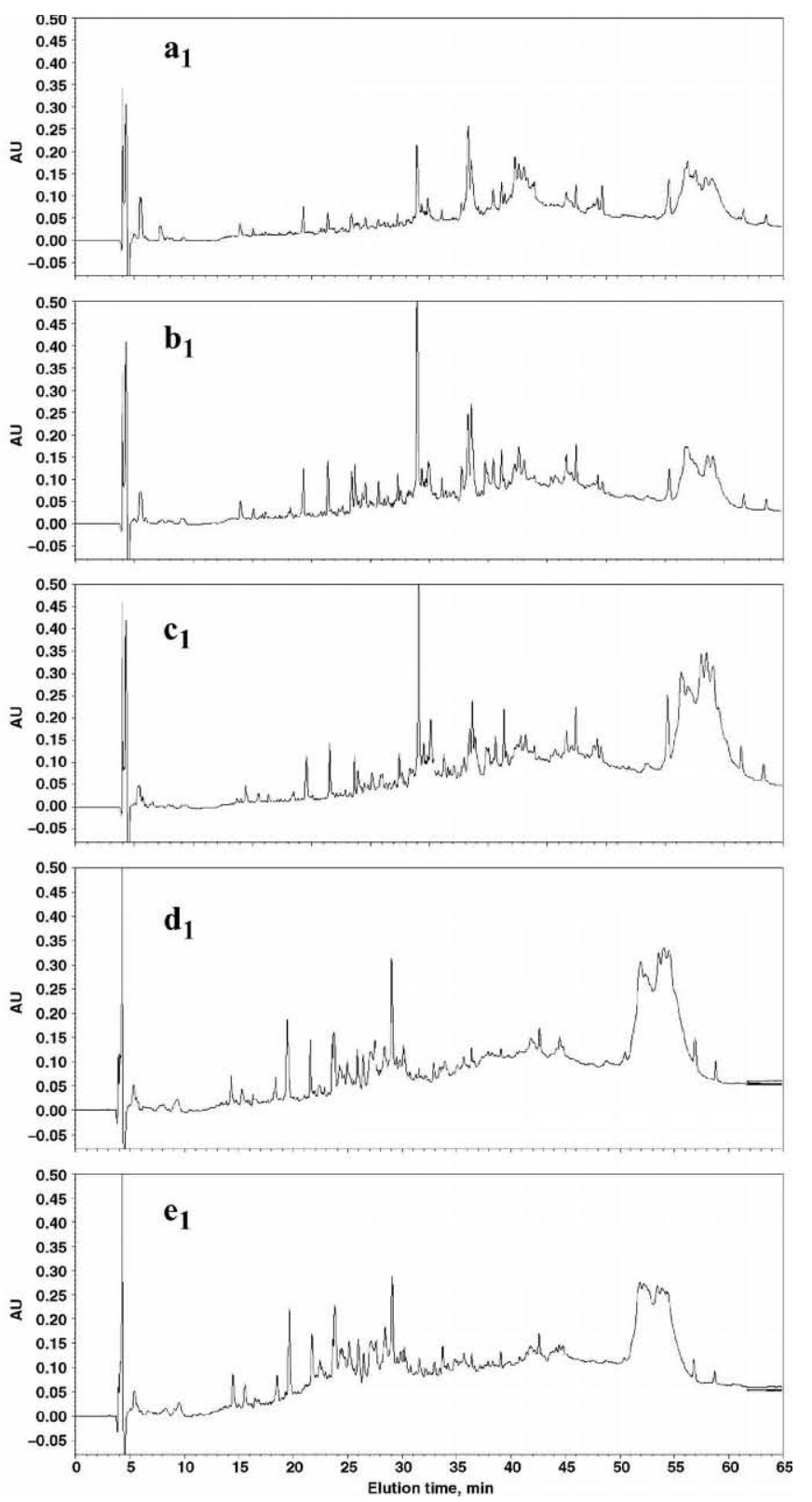

Figure 3. Reversed phase-HPLC chromatograms of the 70\% ethanol-insoluble N (EIN) fraction of Piacentinu Ennese cheese made using traditional (left) or nontraditional (right) technology after $2\left(\mathrm{a}, \mathrm{a}_{1}\right), 4\left(\mathrm{~b}, \mathrm{~b}_{1}\right), 6\left(\mathrm{c}, \mathrm{c}_{1}\right), 8\left(\mathrm{~d}, \mathrm{~d}_{1}\right)$, and 10 mo $\left(\mathrm{e}, \mathrm{e}_{1}\right)$ of age.

imparts to Piacentinu Ennese an amorphous texture as observed in Edam, Gouda (Kalab, 1977), and Prato cheeses (Spadoti et al., 2004). Traditional cheese aged for $2 \mathrm{mo}$ had large empty gaps in the protein matrix, which conceivably held moisture. Over the maturation period (4 to $6 \mathrm{mo}$ ), the microstructure changed to become more compact, with cavities of smaller size, as a result of the gradual loss of moisture caused by the evaporation at the cheese surface. The protein matrix of nontraditional vs. traditional Piacentinu Ennese cheese (Figure $5 \mathrm{~d}, \mathrm{e}, \mathrm{f}$ ) had a coarser and less continuous appearance; this reflected a poorer curd fusion and a more porous matrix. Similar differences were reported by Buffa et al. (2001) for the microstructure of a goats' milk cheese produced from raw and pasteurized milk. The more open structure observed in nontraditional cheeses might have been determined by increased hydration of the protein matrix resulting from milk pasteurization. This effect is known to be a consequence of the decreased fusion of casein micelles caused by the formation of a complex between denatured $\beta$-LG and $\kappa$-CN and to the lower level of soluble $\mathrm{Ca}$ in cheese 

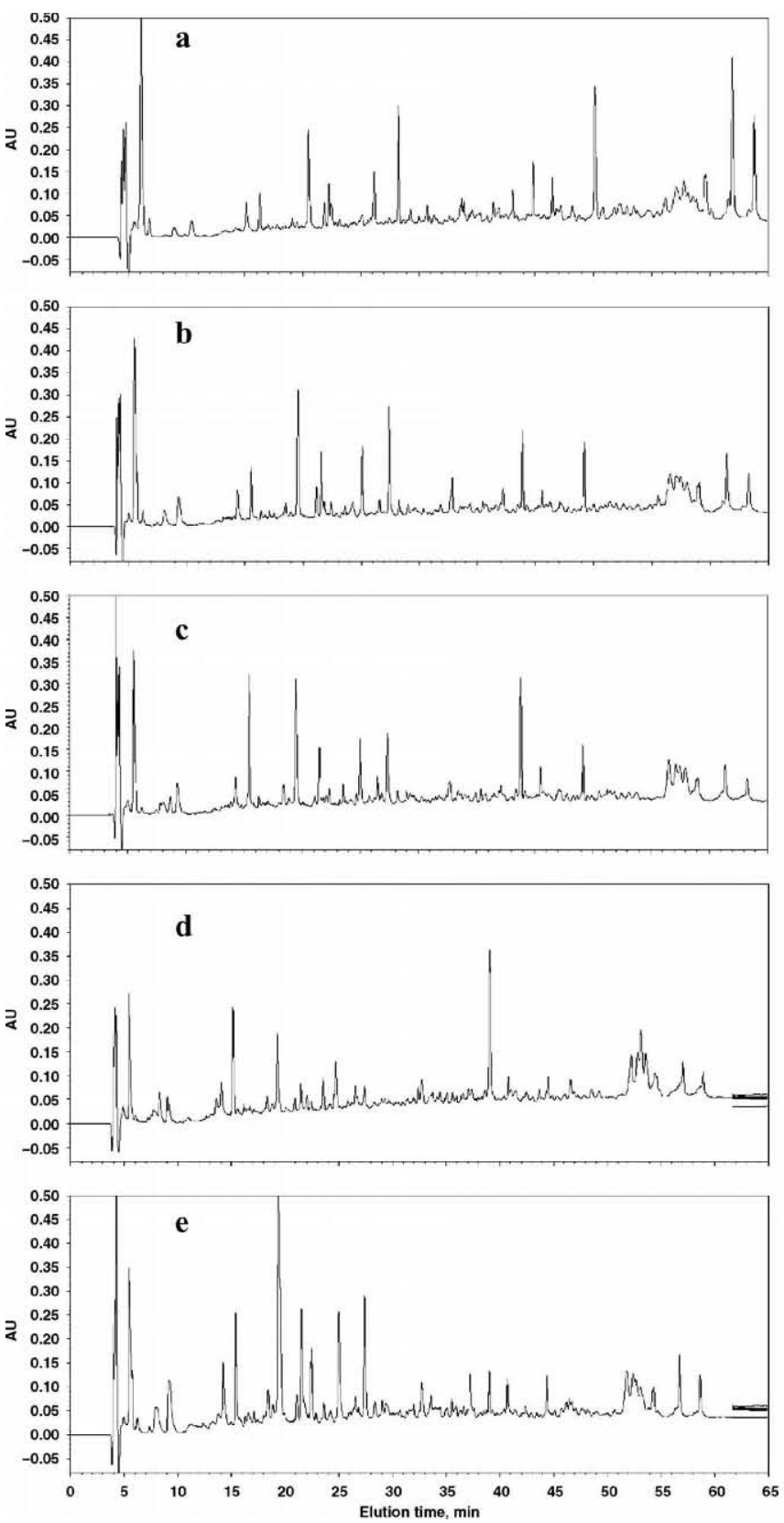
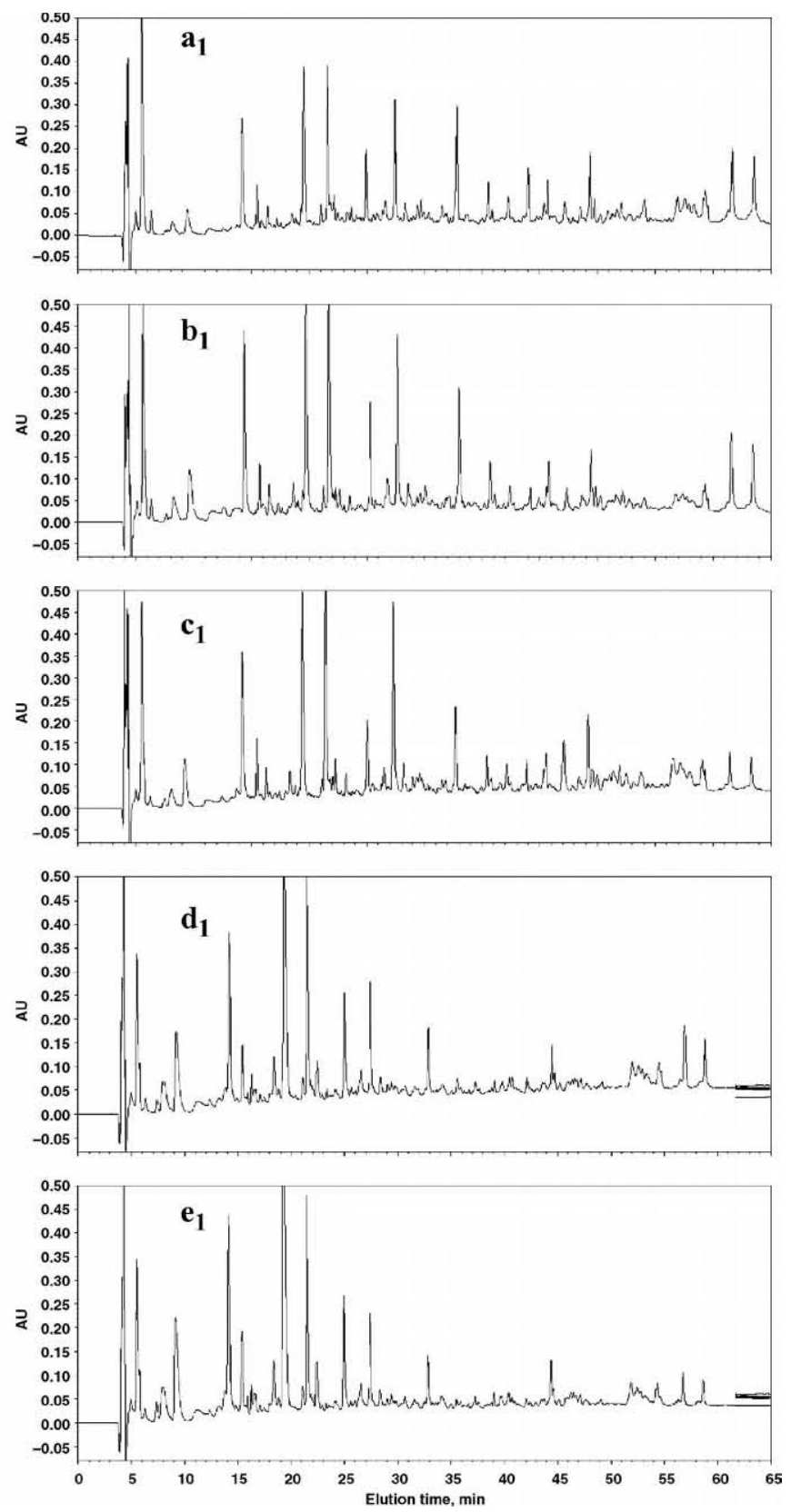

Figure 4. Reversed phase-HPLC chromatograms of the 70\% ethanol-soluble N (ESN) fraction of Piacentinu Ennese cheese made using traditional (left) or nontraditional (right) technology after $2\left(\mathrm{a}, \mathrm{a}_{1}\right), 4\left(\mathrm{~b}, \mathrm{~b}_{1}\right), 6\left(\mathrm{c}, \mathrm{c}_{1}\right), 8\left(\mathrm{~d}, \mathrm{~d}_{1}\right)$, and 10 mo (e, e $\left.\mathrm{e}_{1}\right)$ of age.

produced by heat treatment of milk (Singh and Waungana, 2001; Pastorino et al., 2003). The more open curd structure found in nontraditional cheese was also associated with a higher level of primary proteolysis, in agreement with findings on a semi-hard cheese. Guinee et al. (1995) reported that the lower degree of curd fusion and the greater surface area of the protein matrix, at the protein-void interface, increased the accessibility of the paracasein to proteinases and thereby contributed to higher level of primary proteolysis in cheese.
Scanning electron microscopy examination of traditional and nontraditional Piacentinu Ennese cheese revealed the presence of circular, oval, and kidney-shaped crystalline inclusions associated, singularly or in small aggregates, with the casein matrix (Figure 6a, b). Their morphology was similar to those of the Ca phosphate crystals observed in Mahón (Frau et al., 1997), Grana (Bottazzi et al., 1982), Edam, and Gouda cheeses (Kalab, 1977). These have been reported to originate during cheese ripening by crystallization of $\mathrm{Ca}$ phosphate of 

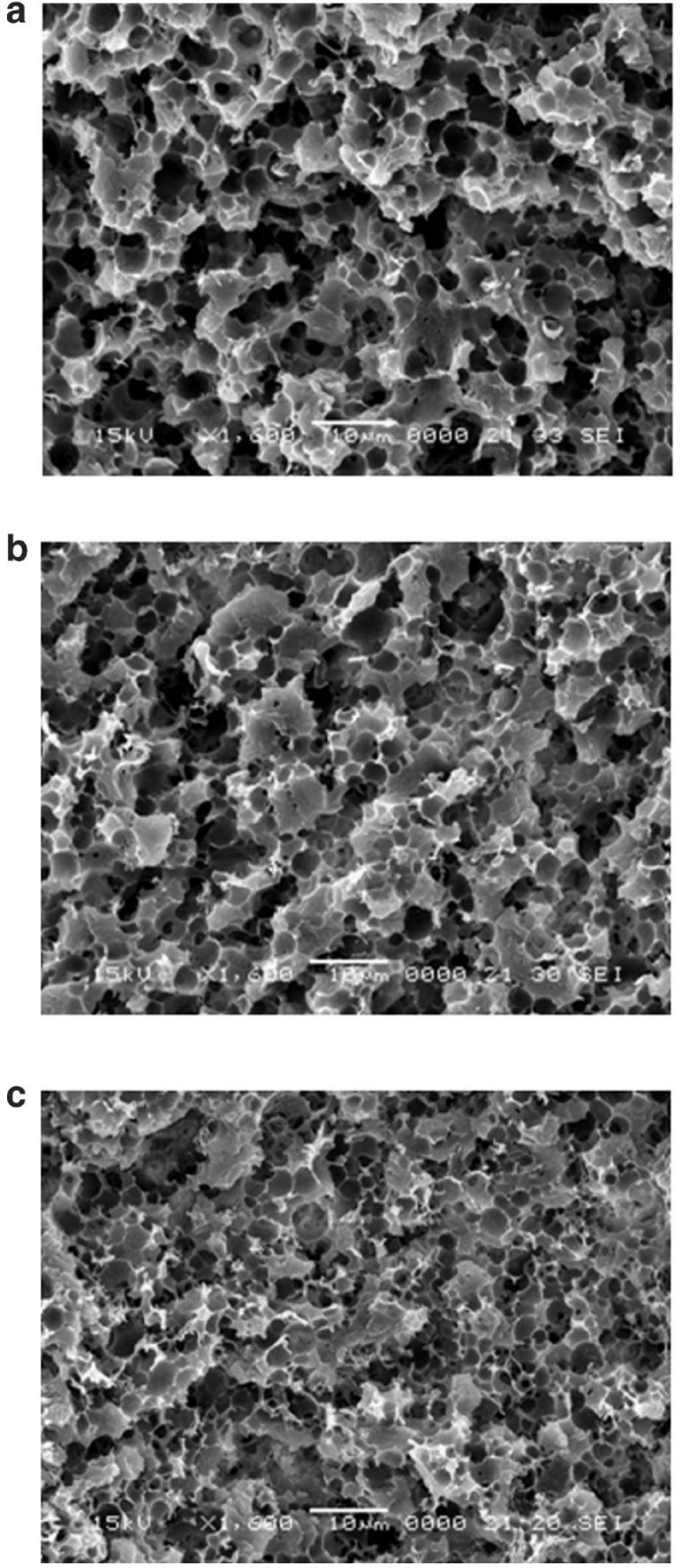
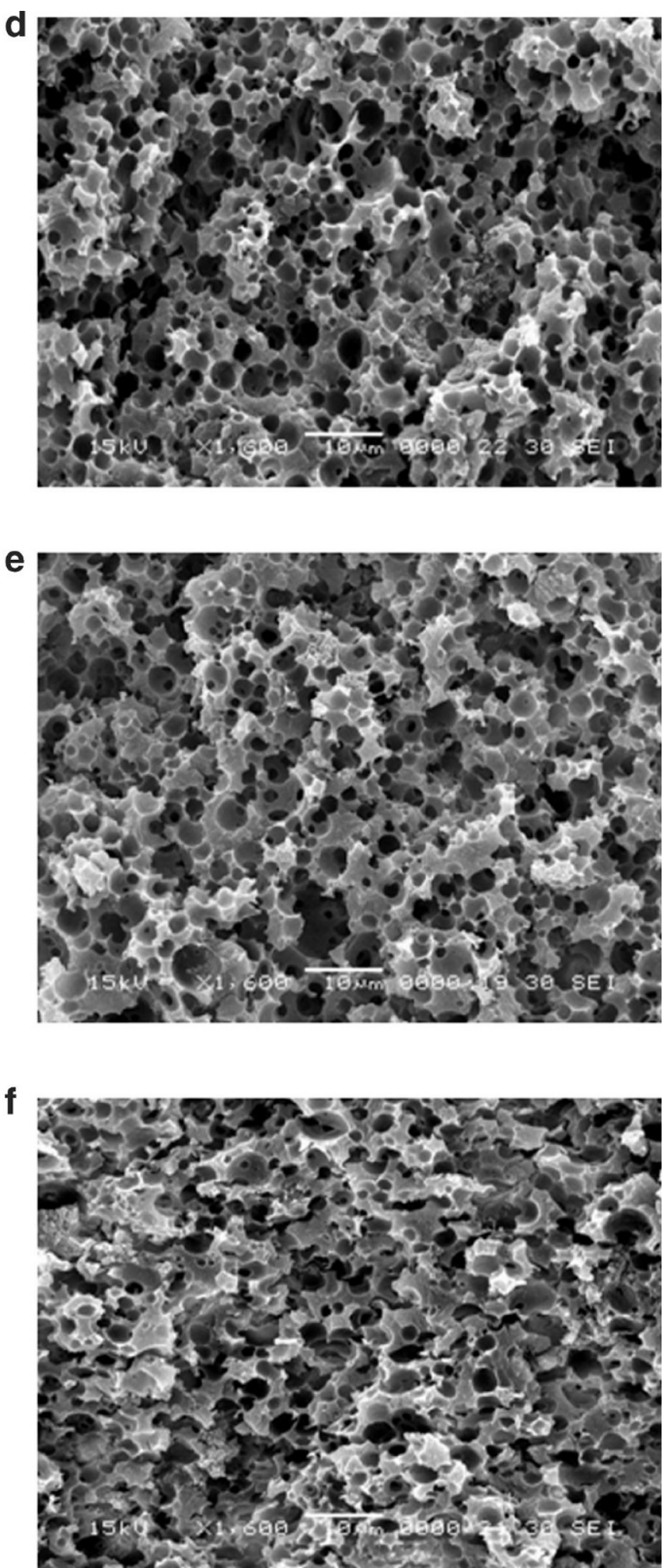

Figure 5. Scanning electron micrographs showing the structure of Piacentinu Ennese cheese made using traditional (left) or nontraditional (right) technology after 2 (a, d), 4 (b, e), and 6 mo (c, f) of age. 
a

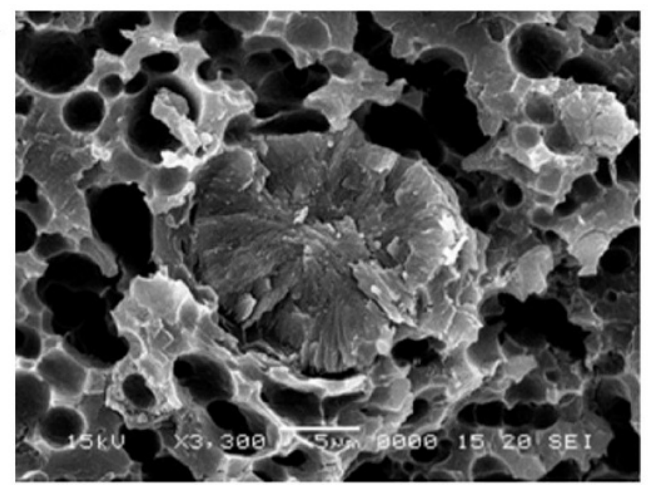

b

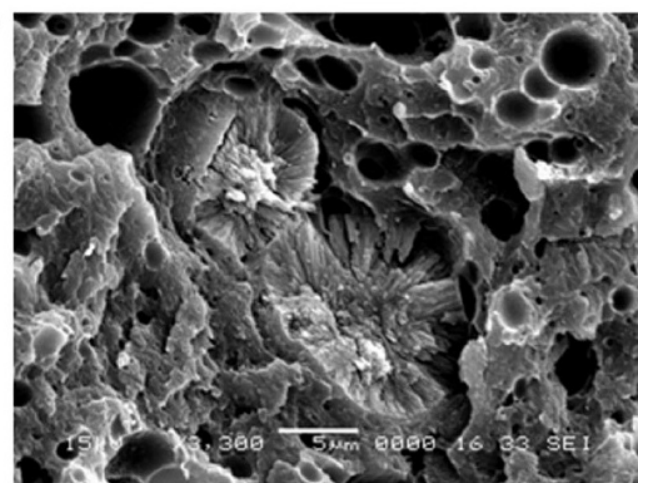

Figure 6. Scanning electron micrographs showing the microstructure of calcium phosphate crystals, singularly associated with the casein matrix (a) or aggregated inside the casein matrix (b).

the residual whey entrapped in the casein network (Brooker, 1987).

\section{CONCLUSIONS}

Piacentinu Ennese cheese undergoes a very low extent of proteolysis during aging, and chymosin plays a major role in regulating the primary hydrolysis of caseins and peptidases from microflora, contributing to the slow formation of small peptides and FAA. These proteolytic rearrangements give rise to a sponge-like microstructure, permeated by a well-distributed system of empty spaces. The cheese structure becomes more compact during ripening, with cavities of smaller size, as a result of the gradual loss of moisture caused by evaporation at the cheese surface.

Results from the comparative study showed that farm technology has a large impact on cheese quality, significantly affecting the development of proteolysis and microstructure in Piacentinu Ennese. The high levels of pH4.6SN and the large hydrolysis of $\alpha_{\mathrm{s}}-\mathrm{CN}$ fractions suggested high residual activity of the commercial rennet paste used for the manufacture of nontraditional cheeses. Similarly, patterns of secondary proteolysis in cheese were largely altered by replacing the native milk microflora by the starter cultures. Nontraditional cheeses had higher levels of TCASN and showed larger proportions of small soluble compounds in the HPLC profiles of the corresponding ESN fraction than traditional cheeses. Changes in rates and extent of proteolysis in nontraditional cheeses were also associated with negative modifications of the structure; nontraditional cheeses had a coarser and less continuous appearance, resulting in a more open structure than traditional cheeses. Furthermore, a large amount of variability was found in cheese proteolysis and structure within nontraditional treatment, reflecting farm-dependent changes in manufacturing conditions related to the use of various types of rennet and starter. Considering that producers are hoping to obtain European recognition as a Protected Denomination of Origin cheese, technology and relative parameters need to be strictly defined to provide a quality range for Piacentinu Ennese.

\section{ACKNOWLEDGMENTS}

The authors thank the technicians of Milk and Derivatives Lab of CoRFiLaC for technical assistance in cheese analysis. Financial support was provided by the Ministero dell'Istruzione, dell'Università e della Ricerca (MIUR), Roma, Italy.

\section{REFERENCES}

Albenzio, M., M. R. Corbo, S. U. Rehman, P. F. Fox, M. De Angelis, A. Corsetti, A. Sevi, and M. Gobbetti. 2001. Microbiological and biochemical characteristics of Canestrato Pugliese cheese made from raw milk, pasteurized milk or by heating the curd in hot whey. Int. J. Food Microbiol. 67:35-48.

Andrews, A. T. 1983. Proteinases in normal bovine milk and their action on the caseins. J. Dairy Res. 50:45-55.

Association of Official Analytical Chemists. 2000. Official Methods of Analysis. 17th ed. Assoc. Off. Anal. Chem., Gaithersburg, MD.

Beresford, T., and A. Williams. 2004. The microbiology of cheese ripening. Pages 287-318 in Cheese: Chemistry, Physics and Microbiology. Vol. 1. 3rd ed. P. F. Fox, P. L. H. McSweeney, T. M. Cogan, and T. P. Guinee, ed. Elsevier Academic Press, London, UK.

Beuvier, E., K. Berthaud, S. Cegarra, A. Dasen, S. Pochet, S. Buchin, and G. Duboz. 1997. Ripening and qualità of Swiss-type cheese made from raw, pasteurized or microfiltered milk. Int. Dairy J. 7:311-323.

Blakesley, R. W., and J. A. Boezi. 1977. A new staining technique for proteins in polyacrylamide gels using Coomassie Brilliant Blue G250. Anal. Biochem. 82:580-581.

Bottazzi, V., B. Battistotti, and F. Bianchi. 1982. The microscopic crystalline inclusions in Grana cheese and their X-ray microanalysis. Milchwissenschaft 37:577-580.

Brooker, B. E. 1987. The crystallization of calcium phosphate at the surface of mould-ripened cheeses. Food Microst. 6:25-33.

Bynum, D. G., and D. M. Barbano. 1985. Whole milk reverse osmose retentates for Cheddar cheese manufacture: Chemical changes during aging. J. Dairy Sci. 68:1-10.

Buffa, M. N., A. J. Trujillo, M. Pavia, and B. Guamis. 2001. Changes in textural, microstructural, and color characteristics during ripen- 
ing of cheeses made from raw, pasteurized or high-pressure-treated goats' milk. Int. Dairy J. 11:927-934.

Centeno, J., J. L. Rodriguez-Otero, and A. Cepeda. 1994. Changes in the protein profile of Arzua cheese (NW Spain) during ripening. Milchwissenschaft 49:319-322.

Creamer, L. K., and N. F. Olson. 1982. Rheological evaluation of maturing Cheddar cheese. J. Food Sci. 47:631-646.

D'Auria, M., G. Mauriello, and G. L. Rana. 2004. Volatile organic compounds from saffron. Flavour Fragr. J. 19:17-23.

Di Cagno, R., J. Banks, L. Sheehan, P. F. Fox, E. Y. Brechany, A. Corsetti, and M. Gobbetti. 2003. Comparison of the microbiological, compositional, biochemical, volatile profile and sensory characteristics of three Italian PDO ewes' milk cheeses. Int. Dairy J. 13:961-972.

Fallico, V., P. L. H. McSweeney, K. J. Siebert, J. Horne, S. Carpino, and G. Licitra. 2004. Chemometric analysis of proteolysis during ripening of Ragusano cheese. J. Dairy Sci. 87:3138-3152.

Fox, P. F., and B. F. Walley. 1971. Influence of sodium chloride on the proteolysis of casein by rennet and by pepsin. J. Dairy Res. 38:165-170.

Frau, M., A. Mulet, S. Simal, J. Massanet, and C. Rosselló. 1997. Microscopic cristalline inclusions in Mahón cheese. Food Sci. Technol. Int. 3:43-47.

Freitas, C., and F. X. Malcata. 2000. Microbiology and biochemistry of cheeses with Appélation d'Origine Protegée and manufactured in the Iberian peninsula from ovine and caprine milks. J. Dairy Sci. 83:584-602.

Gaya, P., M. Medina, M. A. Rodriguez-Marn, and M. Nunez. 1990. Accelerated ripening of ewes' milk Manchego cheese of elevated ripening temperatures. J. Dairy Sci. 73:26-32.

Gazzetta Ufficiale della Comunità Europea. 1996. Regolamento CE n. 1107 della Commissione del 12 Giugno 1996. Registrazione delle indicazioni geografiche e della denominazioni di origine nel quadro della procedura di cui all'articolo 17 del Regolamento (CEE) $\mathrm{n}$. 2081/92. European Community, Brussels, Belgium.

Gobbetti, M., B. Folkertsema, P. F. Fox, A. Corsetti, E. Smacchi, M De Angelis, J. Rossi, K. Kilcawley, and M. Cortini. 1999. Microbiology and biochemistry of Fossa (pit) cheese. Int. Dairy J. 9:763-773.

Gomez, M. J., S. Garde, P. Gaya, M. Medina, and M. Nunez. 1997. Relationship between level of hydrophobic peptides and bitterness in cheese made from pasteurized and raw milk. J. Dairy Res. 64:289-297.

Grappin, R., T. C. Rank, and N. F. Olson. 1985. Primary proteolysis of cheese proteins during ripening. A review. J. Dairy Sci. 68:531-540.

Grappin, R., and E. Beuvier. 1997. Possible implications of milk pasteurization on the manufacture and sensory quality of ripened cheese. Int. Dairy J. 7:751-761.

Guinee, T. P., P. D. Pudja, W. J. Reville, D. Harrington, E. O. Mulholland, M. Cotter, and T. M. Cogan. 1995. Composition, microstructure and maturation of Semi-hard cheeses from high protein ultrafiltered milk retentates with different levels of denatured whey protein. Int. Dairy J. 5:543-568.

Guinee, T. P., and P. F. Fox. 1984. Studies on Romano-type cheese: General proteolysis. Ir. J. Food Sci. Technol. 8:105-114.

Horne, J., S. Carpino, L. Tuminello, T. Rapisarda, L. Corallo, and G. Licitra. 2005. Volatiles, chemical, microbial and sensory characterization of artisanal and industrial Piacentinu Ennese cheese. Int. Dairy J. 15:605-617.

IDF. 1993. Standard Method 20B: Milk. Determination of nitrogen content. Int. Dairy Fed., Brussels, Belgium.

IDF. 1997. Standard Method 152A: Milk and milk products. Determination of fat content (general guidance on the use of butyrometric methods). Int. Dairy Fed., Brussels, Belgium.

Irigoyen, A., J. M. Izco, F. C. Ibánez, and P. Torre. 2000. Evaluation of the effect of rennet type on casein proteolysis in an ovine milk cheese by means of capillary electrophoresis. J. Chromatogr. A 881:59-67.
Kalab, M. 1977. Milk gel structure. VI. Cheese texture and microstructure. Milchwissenschaft 32:449-458.

Kuchroo, C. N., and P. F. Fox. 1982. Soluble nitrogen in Cheddar cheese: Comparison of extraction procedures. Milchwissenschaft 37:331-335.

Lau, K. L., M. Barbano, and R. R. Rasmussen. 1991. Influence of pasteurization of milk on protein breakdown in Cheddar cheese during aging. J. Dairy Sci. 74:727-740.

Lane, C. N., and P. F. Fox. 1996. Contribution of starter lactococci and adjunct lactobacilli to proteolysis in Cheddar cheese during ripening. Int. Dairy J. 6:715-728.

Lynch, C. M., P. L. H. McSweeney, P. F. Fox, T. M. Cogan, and F. B. Drinan. 1996. Manufacture of Cheddar cheese with and without adjunct lactobacilli under controlled microbiological conditions. Int. Dairy J. 6:851-867.

Lynch, C. M., P. L. H. McSweeney, P. F. Fox, T. M. Cogan, and F. B. Drinan. 1997. Contribution of starter lactococci and non-starter lactobacilli to proteolysis in Cheddar cheese with a controlled microflora. Lait 77:441-459.

McSweeney, P. L. H., P. F. Fox, J. A. Lucey, K. N. Jordan, and T. M. Cogan. 1993. Contribution of the indigenous microflora to the maturation of Cheddar cheese. Int. Dairy J. 3:613-634.

Medina, M., and M. Nunez. 2004. Cheeses made from ewes' and goats' milk. Pages 279-299 in Cheese: Chemistry, Physics and Microbiology. Vol. 2. 3rd ed. P. F. Fox, P. L. H. McSweeney, T. M. Cogan, and T. P. Guinee, ed. Elsevier Acad. Press, London, UK.

Mendia, C., F. J. Ibanez, P. Torre, and Y. Barcina. 2000. Effect of pasteurization and use of a native culture on proteolysis in a ewes' milk cheese. Food Contr. 11:195-200.

Ordónez, A. I., F. C. Ibánez, P. Torre, and Y. Barcina. 1999. Effect of ewe's-milk pasteurization on the free amino acids in Idiazábal cheese. Int. Dairy J. 9:135-141.

Pastorino, A. J., N. P. Ricks, C. L. Hansen, and D. J. McMahon. 2003. Effect of calcium and water injection on structure-function relationships of cheese. J. Dairy Sci. 86:105-113.

Prieto, B., I. Franco, J. M. Fresno, J. G. Prieto, A. Bernardo, and J. Carballo. 2004. Effect of ripening time and type of rennet (farmhouse rennet from kid or commercial calf) on proteolysis during the ripening of León cow milk cheese. Food Chem. 85:389-398.

Rosenberg, M., Z. Wang, S. L. Chuang, and C. F. Shoemaker. 1995. Viscoelastic property changes in Cheddar cheese during ripening. J. Food Sci. 60:640-644.

Rousseau, M. 1988. Changes in the microstructure of Saint Paulin cheese during manufacture studied by scanning electron microscopy. Food Microstruct. 7:105-113.

Singh, H., and A. Waungana. 2001. Influence of heat treatment of milk on cheesemaking properties. Int. Dairy J. 11:543-551.

Skeie, S., and Y. Ardö. 2000. Influence from raw milk flora on cheese ripening studied by different treatments of milk to model cheese. Lebensm. Wiss. Technol. 33:499-505.

Spadoti, L. M., J. R. F. Dornellas, and S. M. Roig. 2004. Evaluation of the microstructure of Prato type cheese obtained by modifications of the traditional manufacturing process. Milchwissenschaft 59:151-155.

Sousa, M. J., and F. X. Malcata. 1996. Influence of pasteurization of milk and addition of starter cultures on protein breakdown in ovine cheeses manufactured with extracts from flowers of Cynara cardunculus. Food Chem. 57:549-556.

Sousa, M. J., and F. X. Malcata. 1998. Proteolysis of ovine and caprine caseins in solution by enzymatic extracts from flowers of Cynara cardunculus. Enzyme Microb. Technol. 22:305-314.

Sousa, M. J., Y. Ardö, and P. L. H. McSweeney. 2001. Advances in the study of proteolysis during cheese ripening. Int. Dairy J. $11: 327-345$.

Trujillo, A. J., M. Buffa, I. Casals, P. Fernandez, and B. Guamis. 2002. Proteolysis in goat cheese made from raw, pasteurized or pressuretreated milk. Innov. Food Sci. Emerg. Technol. 11:927-934. 